\title{
Historical Development of the Federalism System in Malaysia: Post-Independence
}

\author{
Wan Kamal Mujani * \\ Department of Arabic Studies and Islamic Civilization, \\ Faculty of Islamic Studies \\ The National University of Malaysia \\ 43600 Bangi, Selangor, Malaysia \\ inawan@ukm.edu.my
}

\author{
Wan Hamdi Wan Sulaiman \\ Department of Arabic Studies and Islamic Civilization, \\ Faculty of Islamic Studies \\ The National University of Malaysia \\ 43600 Bangi, Selangor, Malaysia \\ whamdi88@gmail.com
}

\begin{abstract}
This article discusses the development of the federalism system in Malaysia post-Independence. Before the idea of a constitution was conceived through the Reid Commission, the concept of federalism had already permeated Malaya's administration system through the Treaty of Federation of Malaya but it had not been applied sustainably. After the Reid Commission meetings, the Malaysian government administration was strengthened by the federalism system through the Constitution of Malaysia. This paper aims to investigate the history of the implementation of the federalism system in Malaysia post-Independence. The entire research uses qualitative methods through literature review i.e. historical study and content analysis methods such as an in-depth review of the books in question. This paper finds that after Independence, the federalism system became the foundation of the Malaysian government administration.
\end{abstract}

Keywords-History, Federalism, Malaysia, Post-independence

\section{INTRODUCTION}

After Malaysia achieved its independence, the politics of Malaysia evolved to form a system of power distribution at all levels of government. The distribution of power also affected every agent of administration in Malaysia. The trend of power distribution widely practiced by most countries is described by Wheare in his book Federal Government as one of the characteristics of the federalism system. Wheare believes that the federalist power distribution can occur through three different categories. In the first category, the distribution of power causes the federal government to become weaker than the state government. In the second category, power is more dominated by the federal government compared to the state government and in the third; power is distributed evenly between all levels of government. In his opinion, the true concept of federation is the third category, where power is distributed evenly at all levels of government. Such a federation can only be found in one country and that is the United States of America. The first and second category, in his opinion, is not true concepts of a federation but is merely quasi-federalism. In Malaysia, the existence of more than one authoritative power is manifested through three different forms of government. These are the federal government, state governments, and local governments. Nevertheless, local governments are not elected by the people because they are under the jurisdiction of state governments [1].

\section{CONCEPT OF THE FEDERALISM SYSTEM}

The term federalism came from the word federal which originated from the Latin word foedus. It means a combination of states to form a sovereign union under one political unit which consists of two or more states.

The book Federalism: Origin, Operation, Significance explains the concept of federalism as a separation of power in making decisions that denies negotiations of functions between the federal and state governments.

Conventionally, federalism does not involve interference from any levels of government. This concept at its early stage is heavily influenced by an approach described by Wheare as one where the distribution of power to the federal and state governments has been fixed by the constitution. However, in today's reality, the federalism that now exists is a new kind of federalism referred to as 'relations between governments. Reagan stated the following with regards to the federalism system in the United States: "New style federalism is a political and pragmatic concept, stressing the actual interdependence and sharing of functions between Washington and the states, and focusing on the mutual leverage that each level is able to exert on the other".

Emphasis on the need for freedom at each level of government within their jurisdictional boundaries is also stated in the definition of federalism proposed by Herman Finer. He states that a federalist government is defined by a distribution of power where "powers are distributed between two levels of government i.e. federal and state governments."

The definition of federalism by Elazar and Reagan has formed a more realistic and dynamic approach towards the issue. According to them, the relations between different levels of government exist as a result of the reaction towards socioeconomic pressures. It is not unilateral nor is it divisive between the federal and state governments as proposed by Wheare. 


\section{THE FEDERALISM SYSTEM POST-INDEPENDENCE}

The formation of the Federation of Malaya in 1948 led to Malaya's independence on August 31, 1957 through a remarkable negotiation with the British and tolerance between different racial groups. Before Independence was achieved in March of 1957, the Reid Commission was formed to draft the Constitution of Malaya. This was a vital step in order to achieve independence. One of the essences of the Constitution of Malaya lead by Lord Reid (a judge of the Court of Appeal of England) was to establish a federal government that was strong and stable.

In order to draft the Constitution of Malaya, a commission was appointed as a preparation towards independence. The Reid Commission was named after its chairman, Lord Reid, while other members of the commission include Sir Ivor Jenning (United Kingdom), Sir William McKell (Australia), B. Malik (India) and Hakim Abdul Hamid (Pakistan). The mission of this commission was to recommend a Constitution of Malaya based upon a democratic parliamentary government. The constitution must meet requirements such as the formation of a central government who has authority over the states, emphasis on the status of Malay sultans, the selection of a head of state of the country by the Malay sultans among themselves, a national group for the Federation of Malaya and the special position of the Malays.

The constitutional draft was a result of tolerance between the different racial groups in Malaya towards a few important aspects including the special position of the Malays, the sovereignty of the Malay sultans, and the position of Islam and citizenship affairs. The draft was then revised by a working committee made up of four representatives of the Malay sultans and four representatives from the Alliance Party before it was approved by the Legislative Council. Finally, on August 31, 1957, the independence of the Federation of Malaya was officially proclaimed by Tunku Abdul Rahman and the draft began to act as a legal document [2].

The concept of combining Malaya, Singapore, Sabah, Sarawak and Brunei under the Federation of Malaysia received support from the British government. The British in London then formed a commission under the leadership of Lord Cobbold (the former governor of the Bank of England) to enquire the people's views towards the formation of Malaysia. As a result of the negotiations between the Federation of Malaya and British governments in 1961, a Cobbold Commission was formed to enquire the views of the people of Sabah and Sarawak. In 1962, the commission made a more comprehensive survey in both states. In the middle of 1962, the Cobbold Commission Report was presented and it concluded that almost all of the people of Sabah and Sarawak supported the formation of the Federation of Malaysia. Political parties in both states gave their opinions and views to the commission. The formation of Malaya faced opposition from the United Sabah People's Party who made certain demands. Sarawak was the first to agree to enter or combine with the Federation of Malaysia after their demands were met. Sabah People's Party also rejected Bahasa Melayu as the official language and Islam as the official religion of the Federation of Malaysia. As one of their escapes from Sabah, the United Kadazan National
Organisation agreed with the formation of Malaysia and thought that with it South East Asia's security will be strengthened. Through the idea of Malaysia, a multiracial society would be formed. Evidently the Cobbold Commission Report and the memorandum of the government of Singapore showed the people's support towards the formation of Malaysia. Thus, in 1963, Malaysia was officially established as a combination of Malaya, Singapore, Sabah, and Sarawak. Sabah, Sarawak and Singapore's entry into the Federation of Malaysia brought a tremendous change towards the federalism concept practiced for so long in Malaya.

Singapore entered the Federation of Malaysia only temporarily because they sought their economic and political interests in the combination. Malayan leaders opposed the idea because of two main factors; the racial composition of the people of Malaya was different from that of Singapore and the security threats and political instability was more significant in Singapore than in Malaya. The racial composition of the people of Malaya was a major obstacle towards integration efforts. This was because the position of the Chinese community in the federation as a whole needed to be strengthened with the entry of the Chinese community from Singapore. In the meantime, a political party influenced by communism was already prepared to lead the entire Chinese community. If the two groups of Chinese combined they would form the largest racial group. Due to security threats and political instability, Singapore only achieved self-governance and not a full independence from the British. Thus in 1965, Singapore was separated from Malaysia with the approval of the Federal Government.

According to the book The Major International Treaties of the Twentieth Century: A History and Guide with Texts, in August of 1965, Singapore exited Malaysia with approval from the Federal Government. Even though Singapore exited Malaysia after two years being in the federation, the formation of Malaysia in 1963 is still seen as a successful effort in the integration of territories. To this day, Malaysia still exists with the federalism ideology at every level of government without ignoring the interests of each of its states and citizens [3].

\section{DEVELOPMENT AND AMENDMENT OF THE CONSTITUTION}

Every written constitution experiences a change or can be amended from time to time. Constitutional amendments are made because the attitude, understanding, and demands of the people have changed. Sometimes court decisions also cause the constitution to be amended. Since the Constitution of Malaya was enacted, it has experienced a few changes and amendments. Nevertheless, the changes and amendments made were still within the nature of the original constitution. The changes and amendments made were based on a few changes that occurred in our country. It is a common practice, especially when there is something in the constitution that is perceived as irrelevant. For instance, when the Federation of Malaya transformed into Malaysia with the entry of Sabah and Sarawak, the constitution was amended to make it suitable for the concept of Malaysia. Another incident that leads to a constitutional amendment was the fatal tragedy of May 13, 1969. It relates to the matters of human rights and loyalty to the king and the constitution. 
According to the article Federalism in Malaysia - Change in the First Twenty Years written by Mohd Salleh, the freedom to speak, assemble and form an association indiscriminately without control caused undesirable things to happen. A group from among the Malays, for example, boldly questioned the position of the sultans, the special rights of the Malays and the national language. As a consequence of the fatal tragedy of May 13, 1969, the Parliament in 1967 approved an act that amends Article 10 of the Constitution of Malaysia with regards to freedom of speech, freedom of assembly and freedom of association. There were four matters that were prohibited for public discussion; sensitive matters such as citizenship status, the position of the Malays and the Bumiputeras, the National Language, and the sovereignty of Malay sultans.

The Constitution of Malaysia is also constantly revised from time to time. If necessary, it will be amended and changed based on the demands of the leader and the ruling government. The last time an amendment occurred was when the House of Representatives convened in August of 1983. In the House of Representatives meeting in July of 1983, the House approved a few bills that were later approved by the Senate.

The Constitution of Malaysia can be amended through four different ways, i.e.:

i. By receiving a simple majority

ii. By receiving a two-thirds majority during the second and third readings in both the House of Representatives and the Senate.

iii. By receiving a two-thirds majority during the second and third readings in both Parliamentary meetings and approval from the Conference of Rulers.

iv. By receiving a two-thirds majority during the second and third readings in both Parliamentary meetings and approval from the Head of State of Sabah and Sarawak (for amendments relating to these states) [4].

\section{SUMMARY}

The federalism system in Malaysia that exists today is a result of past historical events. From a retrospective standpoint, the true concept of federalism was never implemented by the British during the administration of Malaya. Instead, the British invasion that lasted over a century (1824-1957) merely gave the inspiration to continue the existing federalism system. The Federalism System in question is the new federalism system that has a strong federal government as recommended by the Reid Commission. To this day, Malaysia still chooses to continue the distribution of powers that sides with the Federal Government. For Malaysia, this approach is the best to guarantee strength, power and stability from economic, domestic and foreign political threats.

\section{ACKNOWLEDGEMENT}

This Research was financially supported by the Arus Perdana Grant - 50 Year Federal Malaya: Achievements, Challenges and The Future (AP-2014-006), The National University of Malaysia.

\section{REFERENCES}

[1] K. C. Wheare, Federal Government, Oxford University Press, New York, Vol. 3, 1953.

[2] Mohd Salleh Abas, Federalism in Malaysia-Change in the First Twenty Years, Tun Mohamed Suffian, H. P. Lee \& F. A. Trindada (e.d), The Constitution of Malaysia its Development 1957-1977, Oxford University Press, London, pp. 163-191, 1978.

[3] J. A. S. Grenville \& B. Wasserstein, The Major International Treaties of The Twentieth Century: A History And Guide With Texts, Routledge, London, 2001..

[4] H. P. Lee, The Process of Constitutional Change in Malaysia, Tun Mohamed Suffian, H. P Lee, \& F. A. Trindade, (e.d), The Constitution of Malaysia its Development 1957-1977, pp. 369-412, Oxford University Press, London, 1978. 